\title{
Mekanik Olarak Aktive Edilmiş Kırmızı Çamurdan Değerli Metallerin Geri Kazanılması
}

\author{
M. Deniz TURAN \\ Metalurji ve Malzeme Mühendisliği Bölümü, Mühendislik Fakültesi, Fırat Üniversitesi, Elazı̆̆, Türkiye \\ mdturan@firat.edu.tr
}

(Geliş/Received: 29/04/2020;

Kabul/Accepted: 02/12/2020)

Özet: Bu çalışmada, Bayer prosesi ile boksitten alüminyum üretimi sırasında ortaya çıkan kırmızı çamurdan metallerin ekstraksiyonu üzerinde mekanik aktivasyonun etkisi incelenmiştir. Orijinal kırmızı çamur örnekleri ve masa üstü tip yüksek enerji aktarımlı bilyeli bir değirmende mekanik aktivasyona tabi tutulmuş örnekler 25 ve $45^{\circ} \mathrm{C}$ 'de $\mathrm{HCl}$ ile liç edilmiştir. Elde edilen sonuçlara göre artan liç sıcaklığı, artan mekanik aktivasyon süresi ve artan $\mathrm{HCl}$ konsantrasyonu ile birlikte metal ekstraksiyon verimlerinin arttığı belirlenmiștir. Ayrıca mekanik aktivasyona tabi tutulmuş örneklerin liç işleminde liç süresinin daha etkin olduğu belirlenmiştir. Elde edilen sonuçlara göre $30 \mathrm{dk}$ mekanik aktivasyon süresi, $120 \mathrm{dk}$ liç süresi, $400 \mathrm{dev} / \mathrm{dk}$ karıștırma hızı, $45^{\circ} \mathrm{C}$ liç sıcaklığı, $3 \mathrm{M} \mathrm{HCl}$ konsantrasyonu ve $25 \mathrm{~mL} / \mathrm{g}$ sıvı-katı oranında \% $100 \mathrm{Al}$, \% $68.51 \mathrm{Ti}$ ve \% 15.08 Fe ekstraksiyon verimleri elde edilmiştir.

Anahtar kelimeler: kırmızı çamur, hidrometalurji, mekanik aktivasyon, alüminyum, titanyum.

\section{Recovery of Precious Metals from Mechanically Activated Red Mud}

\begin{abstract}
In this study, the effect of mechanical activation on the extraction of metals from red mud, which appeared during aluminum production from bauxite by Bayer process, was investigated. Original red mud samples and mechanically activated samples which obtained with grinding in a table type high energy transfer ball mill were leached with $\mathrm{HCl}$ at 25 and $45^{\circ} \mathrm{C}$. According to the results obtained, it was determined that metal extraction efficiency increased with increasing leaching temperature, increasing mechanical activation time and increasing $\mathrm{HCl}$ concentration. Leaching time was found to be more effective in leaching of samples that were subjected to mechanical activation. Under conditions of 30 min of mechanical activation time, $120 \mathrm{~min}$ of leaching time, $400 \mathrm{rpm}$ of stirring speed, $45^{\circ} \mathrm{C}$ of leaching temperature, $3 \mathrm{M}$ of $\mathrm{HCl}$ concentration and $25 \mathrm{~mL} / \mathrm{g}$ of liquid-solid ratio, extraction yields were obtained as $100 \% \mathrm{Al}, 68.51 \% \mathrm{Ti}$ and $15.08 \% \mathrm{Fe}$.
\end{abstract}

Keywords: red mud, hydrometallurgy, mechanically activation, aluminum, titanium.

\section{Giriş}

Doğada alüminyumun çok çeşitli mineralleri olmasına karşılık, dünya alüminyum üretiminin hemen hemen tamamı boksit cevherlerinden sağlanır. Boksit cevherleri ihtiva ettiği alümina mineralleri bakımından farklı sınıflandırılmaya tabi tutulmuştur. $\mathrm{Bu}$ açıdan boksit cevheri alümina $\left(\mathrm{Al}_{2} \mathrm{O}_{3}\right)$, gibsit $\left(\gamma-\mathrm{Al}_{2} \mathrm{O}_{3} \cdot 3 \mathrm{H}_{2} \mathrm{O}\right)$, böhmit $(\gamma$ $\left.\mathrm{Al}_{2} \mathrm{O}_{3} \cdot \mathrm{H}_{2} \mathrm{O}\right)$ ve diasporit $\left(\gamma-\mathrm{Al}_{2} \mathrm{O}_{3} \cdot \mathrm{H}_{2} \mathrm{O}\right)$ alüminyum oksit hidrat minerallerini bulundurabilmektedir [1-2]. Günümüzde boksitten alüminyum üretiminde Bayer prosesi kullanılmaktadır. Bayer prosesi ile alümina üretimi, boksit cevherinin basınçlı bir reaktör sisteminde yüksek sıcaklıkta kostik soda ile muamele edilmesi şeklinde yürütülmektedir. Bayer prosesinde kostik soda ile liç esnasında boksitte bulunan demir katıda kalmakta ve kırmızı çamur adı ile anılmaktadır. Kırmızı çamur, alüminyum üreten tesislerde oldukça fazla miktarda elde edildiğinden dolayı zamanla atık yöntemi gibi çevresel problemleri de beraberinde getirmektedir. Bayer prosesinde bu atığa, kostik rejenerasyonuna tabi tutulmuşsa kahverengi çamur, tutulmamışsa kırmızı çamur ( $\mathrm{pH}$ 10.0-12.5) adı verilmektedir. Üretilen bir ton alümina veya 0.5 ton alüminyum metaline karşılık yaklaşık olarak bir ton kırmızı çamur (kuru baza göre) oluşmaktadır [3].

Diğer taraftan, kırmızı çamurun depolanması aşağıda verilen problemlere yol açabilmektedir:

a) Barajların bakım maliyeti

b) Geniş baraj alanlarının satın alınması

c) Yaşayan organizmalar için kostik riski

d) Barajdan sizıntılar.

Kırmızı çamurun ekonomik olarak işlenmesi konusunda çeşitli metotlar bulunmuş ancak şimdiye kadar pratik bir çözüm geliştirilememiştir. Bu yüzden proses artığı olan kırmızı çamur faydasız bir atık olarak görülmekte ve depolanması her yerde çevresel sorunlara yol açmaktadır. Alümina fabrikaları kırmızı çamurları baraj olarak

* Sorumlu yazar: mdturan @ firat.edu.tr. Yazarın ORCID Numaras1: 0000-0002-2136-1425 
isimlendiren göl tipi alanlarda depolamakta, ancak depolama metotları fabrikadan fabrikaya değişmekte ve çoğu çevreye zarar vermektedir [2].

Birçok metal üretim yönteminde öncelikle minerallerin serbestleştirilmesi gerekmektedir. Bunun için çeşitli boyut küçültme işlemlerine ihtiyaç duyulmaktadır. Balaz vd [4], mekanik aktivasyonu partiküllerin yoğun bir boyut küçültme işlemine tabi tutulması olarak tanımlarken bu esnada kimyasal bazı değişimler gözlemlenirse buna da mekanokimyasal işlemler ismini vermektedir. Yüksek enerjili değirmen sistemleri kullanılması ile meydana gelecek mekanokimyasal dönüşümler partiküllerin aktivitesini arttıracaktır. Mekanik aktivasyonun partikül üzerindeki birincil etkisi tane boyutunda azalma ve buna bağlı olarak yüzey alanında artıs meydana gelmesidir. Partikül üzerinde meydana gelen enerji değişimi katılardaki bağ enerjilerinin azalmasını beraberinde getirmektedir. Diğer taraftan, mekanik aktivasyonun ikincil etkisi agregasyon, adsorbsiyon ve yeniden kristallenme olarak tanımlanmaktadır [5, 6]

Kırmızı çamurdan değerli metallerin geri kazanılmasına yönelik yapılan çalışmalarda çoğunlukla hidrometalurjik yöntemlerin kullanıldığı görülmektedir. $\mathrm{HCl}$ varlığında çeşitli liç parametrelerinin incelendiği bir çalışmada en yüksek çözünme şartlarında çözeltiye $\% 97 \mathrm{Fe}_{2} \mathrm{O}_{3}$ ve $\% 52,2 \mathrm{AI}_{2} \mathrm{O}_{3}$ geçtiği belirtilmektedir [7]. Ayrıca hidroklorik asit ve sitrik asitin kullanıldığı benzer bir çalışmada liç süresinin etkin olmadığı ancak asit konsantrasyonunun sonuç üzerinde oldukça etkin olduğu belirtilmektedir [8]. Diğer taraftan, \% 20'den fazla $\mathrm{Al}_{2} \mathrm{O}_{3}$ içeren kırmızı çamurdaki alüminanın geri kazanımında alkali ilavesindeki artışa bağlı olarak $1400{ }^{\circ} \mathrm{C}$ ye kadar ağırlık kaybında önemli artış olduğu belirtilmektedir [9].

Kırmızı çamurdan alüminanın geri kazanılması üzerine yapılan bir çalışmada soda külü ile sinterlemeyi takiben kostik liç sonucunda alüminanın \% 90'dan fazlasının geri kazanıldı̆̆ı belirtilmektedir [10]. Kırmızı çamurdan çeşitli metallerin geri kazanılması ( $\mathrm{Fe}, \mathrm{Al}, \mathrm{Ti}, \mathrm{Na}, \mathrm{V}, \mathrm{Sc}$ ve $\mathrm{Ga}$ ) ile çevresel açıdan risk potansiyelinin azaltılması $[11,12]$ söz konusu olduğu belirtilmektedir. Yapılan başka bir çalışmada, titanyumun geri kazanılması için iki kademe bir işlem basamağı uygulandığı, sülfürik asit liçini takiben hidroliz ve kalsinasyon işlemlerinin uygulandığı ve $\% 70 \mathrm{TiO}_{2}$ kazanımı elde edildiği belirtilmektedir [13]. Kırımızı çamurda en değerli metal olarak görülen titayumun sülfirik asit liçi ile kazanımının modellenmesi gerçekleştirilmiş liç sıcaklığı, sülfürik asit konsantrasyonu, karıştırma hızı, katı-sıvı oranı ve liç süresi parametrelerinin incelendiği belirtilmektedir [14]. Alüminyumun boksitten veya artıklarından geri kazanılmasında $\mathrm{SiO}_{2} / \mathrm{Al}_{2} \mathrm{O}_{3}$ oranı oldukça önemlidir. $\mathrm{Bu}$ kapsamda yapılan çalışmalarda çeşitli yöntemlerle silisyumun uzaklaştırılmasıyla alüminyum kazanım oranının $\operatorname{arttığı~belirtilmektedir~[15,~18,~19].~Organik~ve~mineral~asitleri~kullanımının~liç~verimi~üzerindeki~etkisinin~}$ incelendiği bir çalışmada farklı kombinasyonlarda kullanılan asitler ile alüminyum kazanımının \% 96'ya kadar çıktığı belirtilmektedir [20, 21]. Yapılan bir çalışmada bir ön muamele olarak sülfürik asidin kullanılması ile öncelikle demirin uzaklaştırıldığ klorürü formunda geri kazanıldığı belirtilmektedir [22]. Ayrıca literatürde kırmızı çamurun altın kazanımında pH modifiyeri olarak kullanıldığı [23] ve değerli metallerin biyo liç ile geri kazanıldığı çalışmalara da rastlanmaktadır [20, 24]. Bu çalışmada, kırmızı çamurdaki çeşitli metallerin çözünürlük davranışı mekanik olarak aktive edilmiş örneklerin $\mathrm{HCl}$ varlığında liç edilmesi ile incelendi.

\section{Materyal ve Metot}

Kırmızı çamur Seydişehir Alüminyum tesisinden temin edilmiştir. Kırmızı çamur halkalı bir öğütücü kullanılarak topaklanmaların dağılması ve belirli bir başlangıç tane boyutuna getirilmesi sağlanmıştır. Eleme işleminden sonra -200 mesh tane boyutuna sahip kırmızı çamur deneylerde kullanılmak üzere kapaklı plastik kaplarda muhafaza edilmiştir. Diğer taraftan söz konusu atığın kimyasal bileşimi mikrodalgada çözünürleştirilmesini takiben elde edilen çözeltilerin ICP ile analiz edilmesiyle gerçekleştirilmiştir. Kırmızı çamurun kimyasal bileşimi Tablo 1'de görülmektedir.

Tablo 1. Kırmızı çamurun kimyasal bileşimi

\begin{tabular}{|c|c|c|c|c|c|c|c|c|c|c|}
\hline \multicolumn{10}{|c|}{ Kimyasal Bileșim (\%) } \\
\hline Fe & $\mathbf{T i}$ & $\mathbf{A l}$ & $\mathbf{N a}$ & $\mathbf{K}$ & $\mathbf{C a}$ & $\mathbf{M g}$ & $\mathbf{P b}$ & $\mathbf{Z n}$ & $\mathbf{C r}$ & $\mathbf{S}$ \\
\hline 23,05 & 2,31 & 9,35 & 7,43 & 0,34 & 0,97 & 0,16 & 0,02 & 0,01 & 0,07 & 0,09 \\
\hline
\end{tabular}

Mekanik aktivasyon işlemi yüksek enerji aktarımlı ve masa üstü tip bilyeli bir değirmende yapılmıştır. Öğütme haznesi öğütülen malzemeye kontaminasyonu düşürmek için tungstenden imal edilmiş olup $80 \mathrm{~mL}$ hacmindedir. Mekanik aktivasyon işlemlerinin tamamı 1/10 kırmızı çamur/bilye oranında gerçekleştirilmiştir. 
Mekanik olarak aktive edilecek malzeme söz konusu hazneye farklı büyüklükte bilyeler ile beslendikten sonra hareketli bir tablaya yerleştirilen öğütme haznesinin hareket ettirilmesi ile öğütme işlemi yapılmıştır (Şekil 1).

Liç deneyleri, 15 adet erleni eşit hızda karıştırmaya imkân tanıyan ve karıştırma hızı ayarlanabilen çoklu manyetik karıştırıcı ve bu karıştırıcı üzerine yerleştirilmiş su giriş-çıkışının yapılabildiği ince camdan imal edilmiş bir küvet düzeneğinde gerçekleştirilmiştir.

Çalışmada, orijinal kırmızı çamur ve mekanik aktivasyona tabi tutulmuş kırmızı çamur örneklerinin liç edilmesi ile çözeltiye geçen metaller karşılaştırmalı olarak incelenmiştir. Liç deneyleri sonunda elde edilen karışım mavi bant süzgeç kâğıdından süzüldükten sonra elde edilen çözeltilerde demir ve alüminyum AAS (Atomik Absorbsiyon Spektrometre-Perkin Elmer A400)' de, titanyum ise UV-spektrometre (Shimadzu UV-VIS mini 1240) kullanılarak analiz edilmiştir. Titanyum analizi, fosforik asit ve hidrojen peroksit varlığında ve iki basamakta gerçekleştirilen bir kompleks oluşumu ile $410 \mathrm{~nm}$ dalga boyunda yapılmıştır. Liç deneyleri 0-30 dk öğütme süresinde elde edilen örneklerin 0.1-3.0 M HCl konsantrasyon aralığında, 25 ve $45{ }^{\circ} \mathrm{C}$ liç sıcaklığında ve $15-120$ $\mathrm{dk}$ liç süresi aralığında gerçekleştirilmiştir.

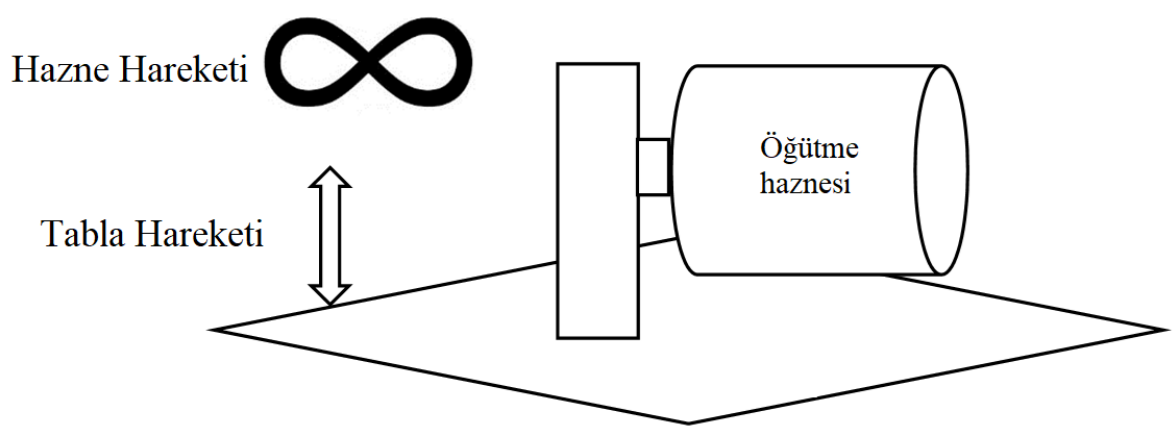

Şekil 1. Masa üstü yüksek enerjili ögütme sistemi

\section{Sonuçlar}

Bu çalışmada, kırmızı çamurda bulunan bazı metallerin çözünürlüğü $\mathrm{HCl} \mathrm{liçi} \mathrm{ile} \mathrm{mekanik} \mathrm{aktivasyona} \mathrm{tabi}$ tutulmuş ve tutulmamış örnekler kullanılarak karşılaştırmalı olarak incelenmiştir.

Liç süresi ve ögütme süresinin metallerin ekstraksiyonu üzerindeki etkisi Şekil 2'de görülmektedir. Şekilde artan öğütme süresi ve liç süresiyle birlikte alüminyum ve titanyum ekstraksiyon veriminin arttığg ancak kırmızı çamurda bulunan demir çözünürlüğünün ise oldukça sınırlı kaldığı görülmektedir. Deneylerde ayrıca artan liç süresi ile birlikte $5 \mathrm{dk}$ öğütme süresinde titanyum ekstraksiyonu üzerinde daha etkin olduğu anlaşılmaktadır. Buna göre $30 \mathrm{dk}$ mekanik aktivasyona tabi tutulmuş kırmızı çamur örneklerinin $120 \mathrm{dk}$ liç edilmesi sonucu alüminyumun neredeyse tamamının çözeltiye geçtiğii, titanyumun yaklaşık \% 35 ve demirin ise yaklaşık \% 5'nin çözündüğü belirlenmiştir. 

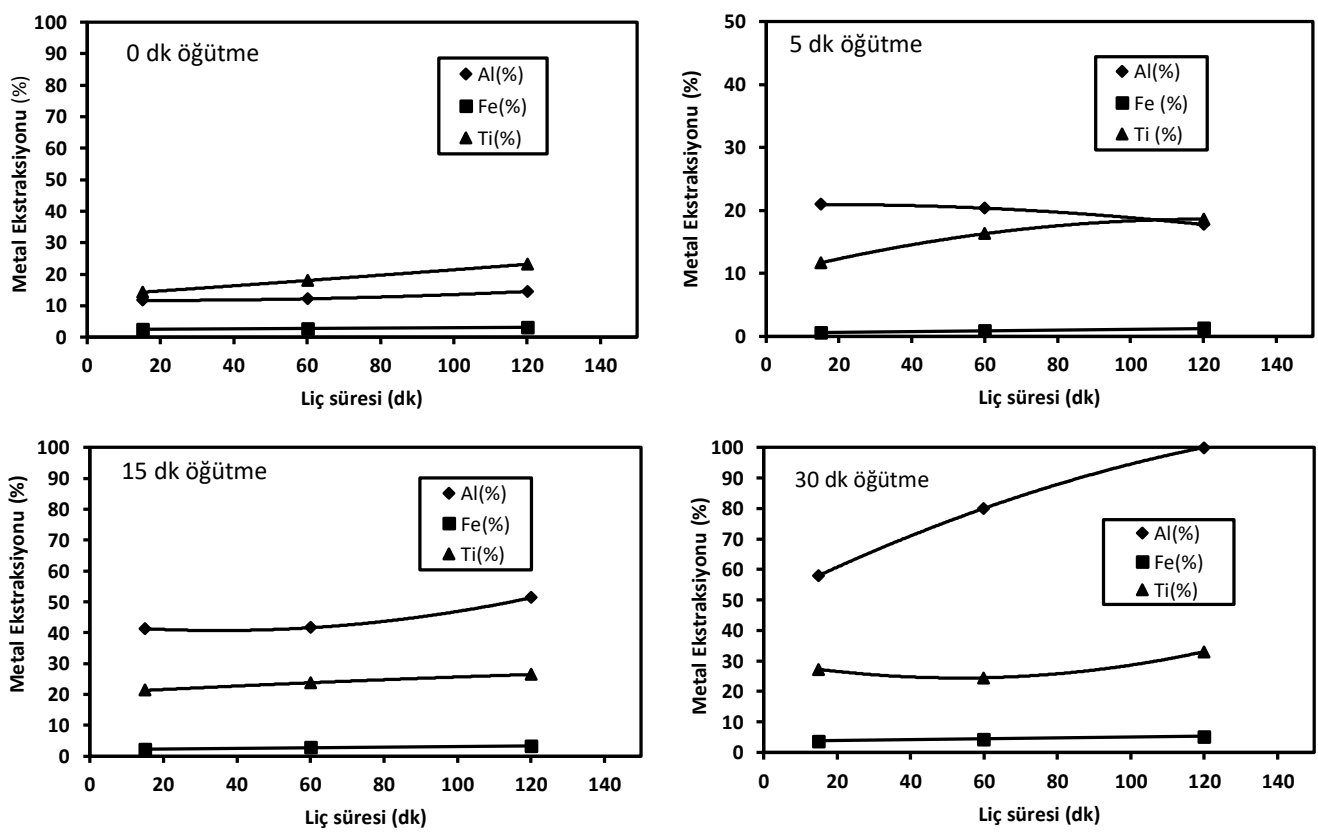

Şekil 2. Liç süresi ve mekanik aktivasyon süresinin metallerin ekstraksiyonu üzerine etkisi (Karıştırma hızı: $400 \mathrm{dev} / \mathrm{dk}$, liç sıcaklığı: $25^{\circ} \mathrm{C}, \mathrm{HCl}$ konsantrasyonu: 3M, sıvı-katı oranı: $25 \mathrm{~mL} / \mathrm{g}$ ).
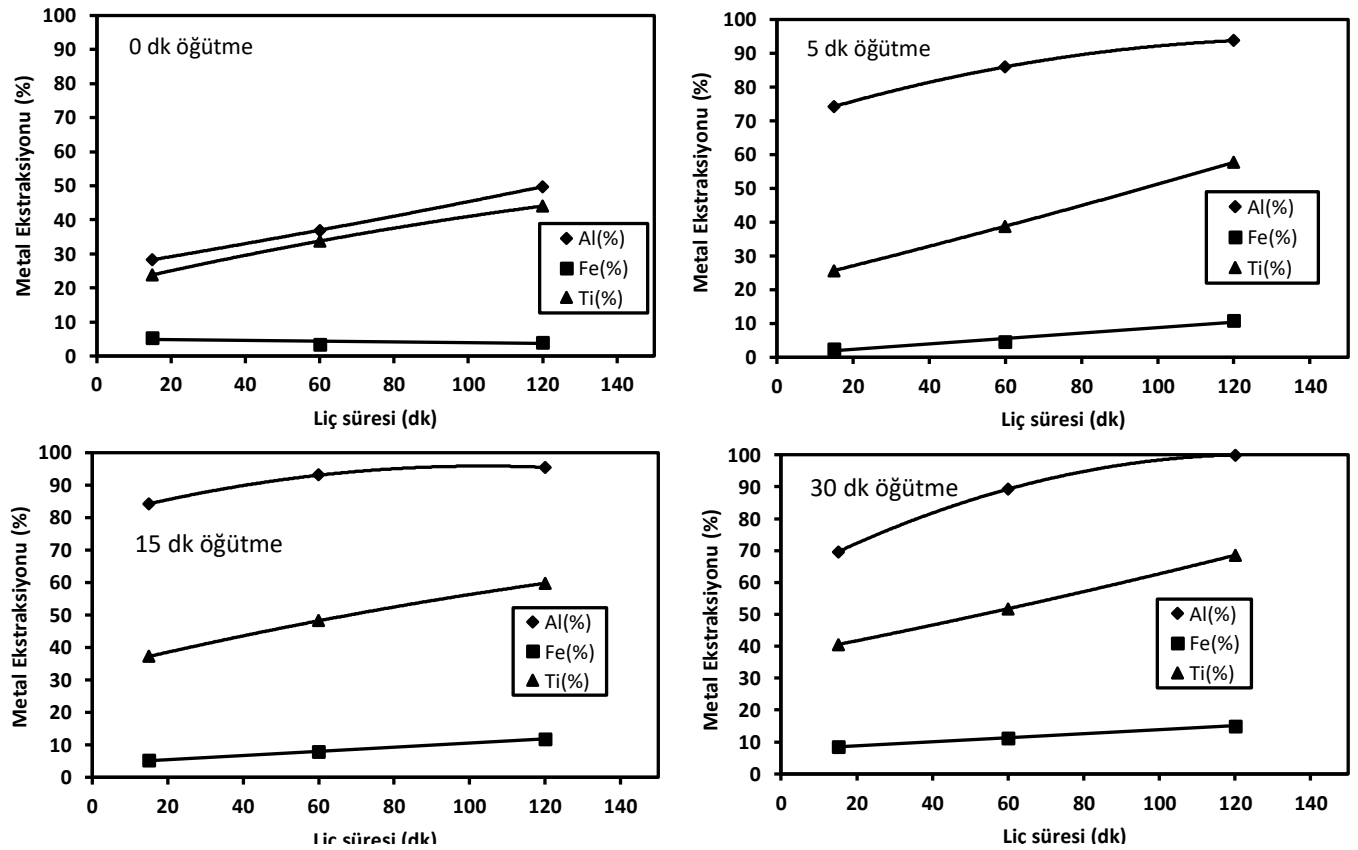

Şekil 3. Liç süresi, mekanik aktivasyon süresi ve artan liç sıcaklığının metallerin ekstraksiyonu üzerine etkisi (Karıştırma hızı: $400 \mathrm{dev} / \mathrm{dk}$, liç sıcaklığı: $45^{\circ} \mathrm{C}, \mathrm{HCl}$ konsantrasyonu: 3M, sıvı-katı oranı: $25 \mathrm{~mL} / \mathrm{g}$ )

Şekil 3'de deneylerin benzer şartlarda ancak $45^{\circ} \mathrm{C}$ liç sıcaklı̆ğında elde edilmiş sonuçları görülmektedir. Şekilde, artan liç sıcaklığı ile birlikte özellikle mekanik olarak aktive edilmiş örneklerde bütün metallerin 
ekstraksiyon veriminde artış olduğu görülmektedir. Buna göre alüminyumun tamamı çözeltiye geçerken demir ve titanyum çözünürlüğü sırasıyla \% 16 ve \% 69 olarak belirlenmiştir. Liç sıcaklığı hidrometalurji çalışmalarında metal çözünürlüğünü olumlu etkileyen etkin parametrelerden biridir. Ancak artan liç sıcaklığı ile birlikte çoğu zaman istenmeyen metallerinde çözeltiye geçmesi söz konusu olduğundan seçimli ekstraksiyonu olumsuz etkilemektedir. Bu çalışmada da benzer bir eğilimin olduğu, liç çözeltileri için kirletici olarak bilinen ve istenmeyen demir iyonlarının artan liç sıcaklığı ile birlikte arttığı anlaşılmaktadır. Diğer bir önemli sonuç ise mekanik aktivasyon ile elde edilen örnekler üzerinde yapılan deneylerde elde edilen metal ekstraksiyon verimleri orijinal örneklerden elde edilenlerden daha yüksek olmasıdır. Görüldüğü üzere artan liç sıcaklığının özellikle mekanik aktive edilmiş örnekler üzerinde daha etkin olduğu anlaşılmaktadır. Bu durumun muhtemel sebebi, mekanik aktivasyon sonucu kırmızı çamurun spesifik yüzey alanda bir artış olması ve artan yüzey alanı ile birlikte liç reaktanının partikül yüzeyinde reaksiyon verme olasılığının artmasındandır. Mekanik aktivasyonun partikül üzerinde en önemli etkisinin öncelikle azalan partikül boyutuna bağlı olarak yüzey alanında meydana gelen artışlar ve uygun şartlarda kristal yapısının bozulmasıdır [25]. Kırmızı çamurun mekanik olarak aktivasyonu ile elde edilen liç verimlerinde görülen belirgin artışın nedeni bahsedilen bu etkenlerin rol alması ile açıklanabilir.

$\mathrm{Bu}$ çalışmadan elde edilen sonuçların benzer yayınlar ile karşılaştırmasında özellikle çözeltiye geçen demir açısından oldukça avantajlı olduğu söylenebilir. Zira, kırmızı çamur ile yapılan diğer çalışmalarda yüksek metal ekstraksiyonu elde etmek için yüksek liç sıcaklıklarında deneyler yapıldığı ve sonuçların bu şartlarda optimize edildiği belirtilmektedir. Ancak yüksek liç sıcaklığı ile birlikte çözeltiye \% 90'dan fazla demirin geçtiği vurgulanmaktadır [7]. Bu çalışmada ise düşük liç sıcaklığında $\left(25\right.$ ve $\left.45^{\circ} \mathrm{C}\right)$ yapılan çalışmalarda özellikle mekanik aktivasyonun olumlu sonuçlarının olduğu ve düşük Fe çözünürlüğüne karşın yüksek Al ve Ti verimleri elde edildiği görülmektedir. $\mathrm{HCl}$ konsantrasyonu etkisini incelemek üzere orijinal örneklerde en yüksek $3 \mathrm{M}$ olmak üzere farklı $\mathrm{HCl}$ konsantrasyonlarında liç deneyleri gerçekleştirildi (Şekil 4). Şekilde görüleceği üzere artan $\mathrm{HCl}$ konsantrasyonu ile birlikte $\mathrm{Al}$ ve Ti ekstraksiyonunda önemli artışlar olduğu görülmektedir. Artan asit konsantrasyonunun özellikle titanyumun çözünürlüğü üzerinde etkisinin fazla olduğu ancak çözeltiye geçen demir üzerinde etkin olmadı̆̆ı söylenebilir.

Son olarak yapılan deneysel çalışmanın bir akım şeması Şekil 5'de görülmektedir.

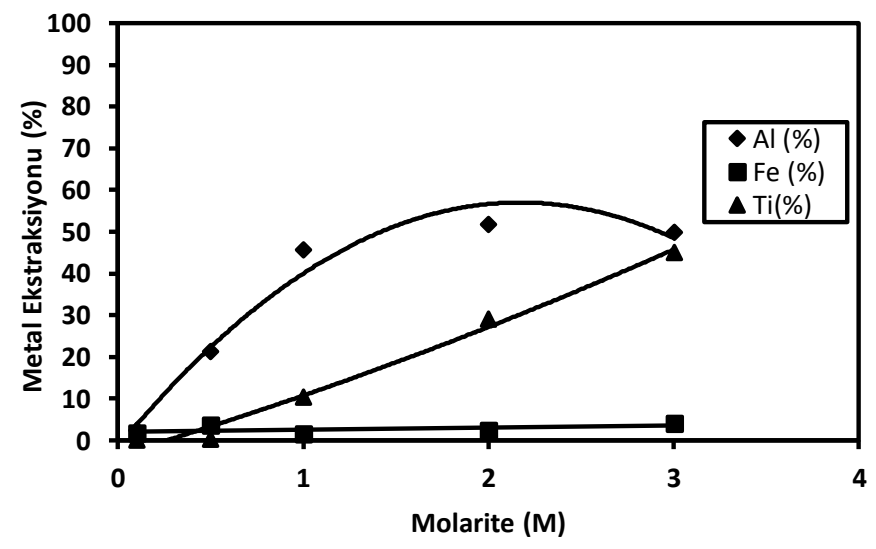

Şekil 4. $\mathrm{HCl}$ konsantrasyonunun metallerin ekstraksiyonu üzerine etkisi (Karıştırma hızı: $400 \mathrm{dev} / \mathrm{dk}$, liç sıcaklığı: $45^{\circ} \mathrm{C}$, sıv1-katı oranı: $25 \mathrm{~mL} / \mathrm{g}$, liç süresi: $120 \mathrm{dk}$, öğütme süresi: $0 \mathrm{dk}$ ). 


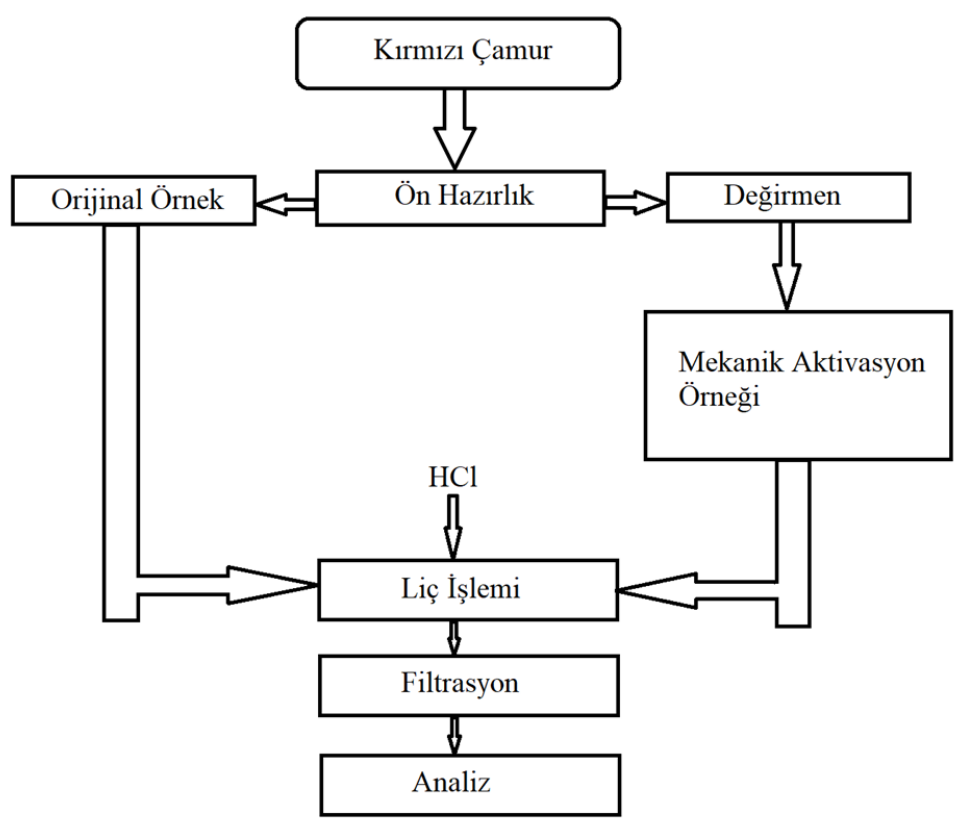

Şekil 5. Deneysel çalışma akım şeması.

\section{Tartışma}

Kırmızı çamurdan metallerin ekstraksiyonu karşılaşırmalı olarak orijinal örnekler ve mekanik aktivasyona tabi tutulmuş örneklerin hidroklorik asit ile liç edilmesiyle incelenmiştir. Mekanik aktivasyon işlemi 1/10 katıbilye oranında masa üstü tip yüksek enerji aktarımlı bilyeli bir değirmende farklı öğütme sürelerinde gerçekleştirilmiştir. Orijinal örnekler ve mekanik olarak aktive edilmiş örneklerin liç edilmesi ve artan liç sıcaklığı ile birlikte özellikle mekanik aktivasyona tabi tutulmuş örneklerin metal ekstraksiyon verimlerinde önemli artışların olduğu belirlenmiştir. Diğer taraftan, elde edilen sonuçlara göre liç süresinin artmasına da bağlı olarak liç sıcaklığının artması metal esktraksiyonu üzerinde etkin olduğu söylenebilir. Ayrıca düşük sıcaklıkta yürütülen çalışmalarda da $\left(25^{\circ} \mathrm{C}^{\prime} \mathrm{de} 30 \mathrm{dk}\right.$ ögüttme süresi) reaksiyonların hızlı yürüdüğü $(15 \mathrm{dk}$ da yaklaşık \% $60 \mathrm{Al}$ ekstraksiyonu) anlaşılmaktadır.

Ayrıca artan hidroklorik asit konsantrasyonun alüminyum ve titanyum ekstraksiyonu üzerinde olumlu etkisinin olduğu belirlenmiştir. Elde edilen sonuçlara göre $30 \mathrm{dk}$ mekanik aktivasyon süresi, $120 \mathrm{dk}$ liç süresi, $400 \mathrm{dev} / \mathrm{dk}$ karıştırma hızı, $45^{\circ} \mathrm{C}$ liç sıcaklığı, $3 \mathrm{M} \mathrm{HCl}$ konsantrasyonu ve $25 \mathrm{~mL} / \mathrm{g}$ sıvı-katı oranında $\mathrm{Al}$, Ti ve Fe ekstraksiyon verimleri surasiyla $\% 100, \% 68.51$ ve $\% 15.08$ olarak belirlenmiştir.

Kırmızı çamur, bünyesinde bulundurduğu metaller ve nadir toprak elementleri açısından gelecekte önemli bir ikincil kaynak olacaktır. Çalışmalarda araştırmacıların çoklu metal ekstraksiyonu üzerinde yoğunlaşması, termal ve mekanik aktivasyonun karşılaştırmalı olarak incelenmesi, elde edilen çözeltilerden nadir toprak elementlerinin solvent ekstraksiyonu ile geri kazanılması önerilir.

\section{Teşekkür}

Deneysel çalışmaların yapılmasında emeği geçen Nuray Köse, Havva Ak ve Aslıhan Cam'a teşekkür ederim.

\section{Kaynaklar}

[1] Uzun D. Kırmızı Çamurdan Demir Ve Alüminyumun Sülfürik Asit Çözeltisindeki Çözünme Kinetiği. Yüksek Lisans Tezi, Sakarya Üniversitesi, Sakarya, Türkiye, 2006.

[2] Gülfen M. Hidroklorik Asit Çözeltisinde Milas Boksit Cevherlerinin Çözünürlüğü. Yüksek Lisans Tezi, Sakarya Üniversitesi, Sakarya, Türkiye, 1998. 
[3] Özgün MA. Kırmızı Çamur Üretimi Ve Değerlendirme Olanakları. Yüksek Lisans Tezi, Süleyman Demirel Üniversitesi Maden Mühendisliği Anabilim Dalı, Isparta, Türkiye, 2012.

[4] Baláž P, Achimovičová M, Baláž M, Billik P, Cherkezova-Zheleva Z, Criado JM, Delogu F, Dutkova E, Gaffet E, Gotor FJ, Kumar R, Mitov I, Rojac T, Senna M, Streletskii A, Wieczorek-Ciurowa K. Hallmarks of mechanochemistry: from nanoparticles to technology. Chem Soc Rev 2013; 42: 7571-7637.

[5] Baláž P. Extractive Metallurgy of Activated Minerals. 1st edn. Elsevier Science B.V., Amsterdam 2000. ISBN: 0444 50206 8. Sayfa: 9-124.

[6] Haug TA. Dissolution and carbonation of mechanically activated olivine-Investigating CO2 sequestration possibilities, Thesis for the degree of Philosophiae Doctor, Norwegian University of Science and Technology, ISBN 978-82-471-19600 (printed ver.), Sayfa: 25-26, Norveç, 2010.

[7] Aksu S. Kırmızı Çamurun Temel Bileşenlerinin Hidrojen Klorür Çözeltisindeki Çözünürlükleri. Yüksek Lisans Tezi, Sakarya Üniversitesi Kimya Anabilim Dalı, Sakarya, Türkiye, 2001.

[8] Selcen T, Kalsen A. Kırmızı Çamurdaki Değerli Metallerin Hidrometalurjik Proseslerle Kazanılması. Yüksek Lisans Tezi, Yıldız Tekink Üniversitesi Metalurji Mühendisliği Anabilim Dalı, İstanbul, Türkiye, 2018.

[9] Goral MS. Kırmızı Çamurdan Alümina’nın Geri Kazanımında Verimlilik Koşullarının Araştırılması. Yüksek Lisans Tezi, Sakarya Üniversitesi, Sakarya, Türkiye, 1999.

[10] Mishra B, Staley A, Kirkpatrick D. Recovery of value-added products from re mud, Min Mett Proc 2002; 19 (2): 87-94.

[11] Liu W, Yang J, Xiao B. Application of Bayer red mud for iron recovery and building material production from alumosilicate residues. J Hazard Mater 2009; 161 (1): 474-478.

[12] Smirnov DI, Molchanova TV. The investigation of sulphuric acid sorption recovery of scandium and uranium from the red mud of alumina production. Hydrometallurgy 1997; 45 (3): 249-259.

[13] Yu Z, Shi Z, Chen Y, Niu Y, Wang Y, Wan P. Red-mud treatment using oxalic acid by UV irradiation assistance. Trans Nonferrous Metal Soc 2012; 22 (2): 456-460.

[14] Zhang R, Zheng S, Ma S, Zhang Y. Recovery of alumina and alkali in Bayer red mud by the formation of andraditegrossular hydrogarnet in hydrothermal process. J Hazard Mater 2011; 189 (3): 827-835.

[15] Zhong L, Zhang Y, Zhang Y. Extraction of alumina and sodium oxide from red mud by a mild hydro-chemical process. J Hazard Mater 2009; 172 (2-3): 1629-1634.

[16] Zimmer E, Nafissi A, Winkhaus G. Eclamation treatment of redmud. US patent US4119698, 1978.

[17] Şayan E, Bayramoğlu M. Atık Kırmızı Çamurdan TiO2'nin Seçimli Liçinin Modellenmesi. II. Mühendislik Bilimleri Genç Araştırmacilar Kongresi MBGAK, İstanbul 17-19, 2005.

[18] Ablamoff B, Qian-de C. Physical and Chemical Principles of Comprehensive Treatment of Aluminum-containing Raw Materials by Basic Process. Central South University of Technology Press 1988; 178-182.

[19] Liu Z, Yang C, Cheng Z, Ai M. Treatment and utilization of red mud derived from Bayer process. Chin J Nonferrous Metal 1997; 7 (1): 40-44.

[20] Vachon P, Tyagi RD, Auclair JC, Wilkinson KJ. Chemical and biological leaching of aluminum from red mud. Environ Sci Technol 1994; 28 (1): 26-30.

[21] Bosecker K. Bacterial metal recovery and detoxification of industrial waste. Biotechnology and Bioengineering Symposium, Wiley, 1986.

[22] Uzhidy A, Borlai O, Szabo P, Jelinko R, Szepvolygi J, Fenyi G, Szabo M. Processing low-quality alumina-containing ores by selective chlorination of iron. Hungarian Patent 181729, 1983.

[23] Browner RE. The use of bauxite waste mud in the treatment of gold ores. Hydrometallurgy 1995; 37: 339-348.

[24] Yang Q, Bin L, Binbin M, Congqiang L. Bioleaching of heavy metals from red mud using Aspergillus niger. Hydrometallurgy 2013; 136: 71-77.

[25] Turan MD, Altundoğan HS, Boyrazlı M, Sarı ZA, Nizamoğlu H, Demiraslan A. Basic Leaching Behavior of Mechanically Activated Zinc Plant Residue, Trans Indian Ins Met 2019; 72 (9): 2359-2364. 